\title{
Impact of technology on Translation and Translation Studies ${ }^{1}$
}

\author{
Yves Gambier \\ University of Turku \\ Fi-20014 Turun Yliopisto, Finland \\ I. Kant Baltic Federal University \\ 14, A. Nevskogo st., Kaliningrad, 236041, Russia
}

\begin{abstract}
The landscape in translation and interpreting is changing deeply and rapidly. For a long time, but not necessarily everywhere, translation was denied as a need (except for the political and religious powers), as effort (translation being defined as a kind of mechanical work, as substitution of words), and as a profession (translators embodying a subaltern position). Technology is bringing in certain changes in attitudes and perceptions with regards international, multilingual and multimodal communications. This article tries to define the changes and their consequences in the labelling and characterisation of the different practices. It is organised in five sections: first, we recall that translation and interpreting are only one option in international relations; then, we explain the different denials of translation in the past (or the refusal to recognize the different values of translation). In the third section, we consider how and to what extent technology is transforming today practices and markets. The ongoing changes do not boil solely to developments in Machine Translation (which started in the 1960s): community, crowdsourced/collaborative translation and volunteer translation encompass different practices. In many cases, users provide their own translations, with or without formal qualifications in translation. The evolution is not only technical but also economic and social. In addition, the fragmentation and the diversity of practices do have an impact on a multi-faceted market. In the fourth section, we emphasize that there are nowadays different concepts of translation and competitive paradigms in Translation Studies. Finally, we tackle the organisational challenge of the field, since the institutionalisation of translation and Translation Studies cannot remain the same as when there was a formal consensus on the concept of translation.
\end{abstract}

Keywords: translation, Translation Studies, concepts of translation, paradigms in Translation Studies

\section{For citation:}

Gambier, Yves (2019). Impact of technology on Translation and Translation Studies. Russian Journal of Linguistics, 23 (2), 344-361. doi: 10.22363/2312-9182-2019-23-2-344-361.

${ }^{1}$ Part of this article has been elaborated from data and reflections which have been first discussed in English in a conference held in Vilnius, Lithuania (October 2011) and then developed in a text published in French in TTR 26 (2), 2013. 


\title{
Влияние инновационных технологий на перевод и переводоведение
}

\author{
Ив Гамбье \\ Университет Турку \\ Fi-20014 Turun Yliopisto, Финляндия \\ Балтийский федеральный университет им. И. Канта \\ ул. Александра Невского, 14, Калининград, 236041, Россия
}

\begin{abstract}
Аннотация
Профессия письменного или устного переводчика претерпевает значительные и быстрые изменения. В течение долгого времени, хотя и не повсеместно, отрицалась сама потребность в переводе (за исключением перевода в политических или религиозных целях), перевод не рассматривался как деятельность, требующая определенных усилий и умений (перевод воспринимался как сугубо механическая работа по замене слов одного языка словами другого языка), либо перевод отрицался как профессия (считалось, что переводчики занимают подчиненное положение). Новые технологии привносят изменения в восприятие всего того, что относится к международной, многоязычной и мультимодальной коммуникации. В настоящей статье рассматриваются эти изменения, а также их последствия для обозначения и характеристики различных переводческих практик. Статья включает пять разделов. В первом мы укажем на то, что устный и письменный перевод являются одной из форм межкультурной коммуникации, затем мы остановимся на различных аспектах отрицания перевода в прошлом (или на отказе признать ценность перевода). В третьем разделе мы рассмотрим, каким образом и насколько технологии меняют переводческую деятельность и переводческий рынок. Эти изменения не сводятся только к развитию систем машинного перевода (начало которому было положено в 60-е годы прошлого века), к их числу относится и появление группового перевода, краудсорсинга и волонтерского перевода. Во многих случаях потребители перевода, даже не имеющие соответствующей квалификации в области переводческой деятельности, самостоятельно выполняют перевод. Эти изменения затрагивают не только технические аспекты переводческой деятельности, но и социально-экономические. Кроме того, разграничение и многообразие видов переводческой деятельности оказывают существенное воздействие на весьма разнообразный переводческий рынок. В четвертом разделе речь идет о существовании в переводоведении различных противоборствующих концепций и парадигм перевода. Наконец, мы рассматриваем организационные аспекты переводческой деятельности, поскольку сама институционализация перевода и переводоведения не может быть такой же, какой она была в эпоху существования формального консенсуса по поводу сущности переводческой деятельности.
\end{abstract}

Ключевые слова: кониепиии перевода, перевод, переводоведение, переводоведческие парадигмы

\section{Для цитирования:}

Gambier, Yves. Impact of technology on Translation and Translation Studies // Вестник Российского университета дружбы народов. Серия: Лингвистика = Russian Journal of Linguistics. 2019. Т. 23. No 2. C. 344 -361. doi: 10.22363/2312-9182-2019-23-2-344-361.

\section{TRANSLATION AND INTERPRETING: AN OPTION}

With their arrival, communication, information and computer technologies (ICTs) have brought about certain changes in attitudes and representation with regards to translation. What follows here hinges on a main proposition, i.e. that these changes may well induce a significant break not only in translation practice but also in the discourses about translation. 
Firstly, and with the goal of putting these changes more clearly into focus, we need to recall that translation and interpreting are but one possible solution among many implemented in international, multilingual communications and relations. Indeed, depending on the historical period and specific power relations, other means and strategies have existed and been valorised in different ways over time (Lambert, 1989: 233):

- The language of the Other can be recognized and learned - a long-term investment which may ultimately yield results that are less risky and less costly than translation/interpreting and ultimately favour linguistic and cultural diversity (see efforts to promote multilingualism by the European Union).

- Languages can co-exist, with speakers alternating between languages or practicing a passive bilingualism (each one speaking his/her own language, without having to pass through any type of mediation whatsoever).

- A lingua franca can be used - and this language can be either an imposed one (for ex. Russian in the former eastern European countries), or an artificial one (ex. Esperanto), or a third language (for ex., French in certain African countries, or English as in Belgium or in Switzerland....so as not to have to choose one of the local languages). Today, English fulfils this function in the domains of science and business and commerce (House, 2003), as Latin once did for the world of letters. A lingua franca can also act as a pivot language, to the detriment of direct bilateral contacts (Gambier, 2003).

In addition to these co-operative strategies, with all the possible difficulties and misunderstandings that they imply, we find at least two other strategies that are exclusionary:

- A barricade can be imposed, closing the Self in behind a wall so as not to be exposed to the Other, effectively a separation from 'them' — and we think here of the Great Wall of China, the Roman walls, the walls/ramparts of Medieval cities, the Berlin Wall, the so-called Security Fence between Israel and the Palestinians, the enclosures separating the U.S. from Mexico, or those erected between the Spanish enclaves and Morocco, and even the surveillance cameras of gated communities or ghettos of the elite!

- The Other can be suppressed, in favour of ethnic purging and purification, and ethnocide. Recent examples (ex-Yugoslavia, Rwanda, Cambodia) clearly confirm that this solution is not one relegated solely to the past.

This short reminder allows us to re-position translation in terms of linguistic policy struggles ${ }^{2}$, and to brush away all specks of naiveté concerning the inexorable growth in demand for translation. In this picture we've sketched out, there is no mention made of the diverse possibilities to automate translation; yet, translation automation already satisfies a not insignificant volume of translation, of a more or less urgent nature (see section 3.2). From this perspective, how and up to what point do these possibilities challenge the place, indeed, even the role, of translation? And above all, how do they transform the perception we have of them?

2 Translation markets (literary, scientific) are at least doubly structured, both by linguistic borders and by nation-states, and the two do not necessarily coincide. Furthermore, both are respectively structured between center and periphery (for ex., Francophone countries constituting La Francophonie). 


\section{DENIALS OF TRANSLATION AND TABOOS IN TRANSLATION STUDIES}

Translation, taken in its traditional sense (as some kind of equivalence), has been denied in several aspects all at once. All languages and societies have not been affected in the same way, to the same degree, at the same time. The thoughts and remarks mentioned below should thus be taken prudently, and not be over-generalized in an abusive way.

\subsection{Denial of translation as a need}

For a long time, it seemed as though translation only served the powers that be and the established authorities (royal and religious), as if it were inexistent, hidden away tucked within exchanges of all types - commercial, scientific, and philosophical, to name but a few (Delisle \& Woodsworth, 2012). Non-translation has been discussed and debated (by Toury, for ex., 1995: 23-29). This non-recognition of a translation status for some documents, as is largely the case for televised advertising and news, makes it difficult to grasp the actual volume of translation work taking place, the change in the job market and the amount of graduates to train for the near future (see section 3.3).

\subsection{Denial of translation as effort}

Denial has always been present, and still is, with regard to translation as an activity requiring effort. Many sponsors, amateurs, self-translators (scholars translating their own articles), and engineers within the language industry continue to consider translation as a mechanical process, the replacement of one word by another, a problem of dictionaries, something they could do themselves if they had the time but which they prefer to pass on, not without condescension, to a cousin who knows languages, or to a bilingual secretary, or, worse, to a professional translator, on the condition that he or she doesn't demand too much financial compensation. The lay person thinks of translation in the equivalence paradigm, or the quest to convey identical meanings (see 4.2). There are strong assumptions underlying such an approach. It assumes, for instance, that two languages "do or can express the same values" (Pym, 2009, p. 82). But a word or concept may connote different meanings in another language or may be absent altogether, so the relationship between the two languages is not necessarily symmetrical. Two words may also refer to the same object, and this would not necessarily convey the intended meaning of the original text. Loyalty to the source text may result in a text that is not easily comprehensible in the target language. The implicit assumptions of the equivalence paradigm usually compel people to criticize a translation because certain words have not been replaced. Thus, the famous set phrase: "Traduttore traditore". This focus on the lexical similarity of texts, however, is misguided. It does not allow one to consider, describe, and explain the translation decisions and the translated output. The distinction between what is manifest (literal, direct, surface-level) and what is latent (implicit, connotative, underlying) 'misreads' the process of translation, and relegates the translator's act of interpreting the content to a task of relative obscurity. Perceiving a text to be translated as nothing more than a linear series of words or phrases no doubt explains why translation has long been considered as inferior, subordinate, second only to the 
original - thus the recurring diatribes on "lost in translation", as if translators could only hope to level out, neutralize, render insipid, in their desperate effort to find equivalence in what could only be an affair of words, without stakes, without cultural complexity. In that perspective, it is easy to understand that the only "translation" to be recognised and legitimized is the literary one, even though the translation of literary texts and genres represent roughly less than $5 \%$ of the daily work of the translators.

\subsection{Denial of translation as a profession}

Denial has likewise been present with regard to translation as a profession, notably by translators themselves who have integrated, incorporated, and internalized various aspects of the "subaltern" in their work, caught between the sacrificial idealism and the calculating materialism of their activity, all the while taking on the labour and servility of their always precarious "vocation" as if this job or this practice required a certain predisposition towards effacement and docility (Kalinowski, 2002; Simeoni, 1998; Buzelin, 2014), even self-destruction (with translators taking pleasure in denigrating themselves among themselves).

Metaphors of translation and images of the translator in the collective imagination are today regularly reproduced in fiction, novels, films, and even in the media (Gambier, 2012). They verge on the stereotypical and on clichés, with the translator viewed more often as a hardworking hermit, on the margins, an impostor, instead of a mediator, an expert, a creator. Since the end of the Middle Ages $\left(15^{\text {th }} \mathrm{c}\right.$.), one finds mention of imagery associated with reflection, the pale star, the underside of tapestries, the chameleon, etc.

\subsection{Denial of translation as a discipline}

Finally, denial has long been present with regard to translation as an autonomous discipline. Even today, the status of Translation Studies (TS) remains an ambiguous one within university institutions: it is often caught between languages and literature. Furthermore, many of the translator training programs emerging and multiplying over the past few years have been reluctant to give Translation Studies a place, reducing translation to a collection of knowledge and tricks of the trade, unfit for self-reflexivity. Such ambiguity reflects the malaise of universities when confronted with interdisciplinary, intercultural communication, and linguistic diversity, even when at this very moment the globalization of business and trade, and migration, continuously hurl challenges at most of our societies.

Will the types of denial mentioned resist the transformations currently underway and which make the translator an ever more "dematerialized" individual, one no longer reducible to mere pens and dictionaries? Before answering the question, let's look at the recent past of Translation Studies.

TS has clearly experienced "turns" over the past three decades (linguistic, cultural, ideological, semiotic, cognitive, sociological, etc.), turns which are somewhat dizzying, as if this bulimia of bends, turns and detours were more a condition of driving while under the influence. Such turns are a certain angle, a reductionist view to investigate translation as a complex reality, a way of splitting up our knowledge, a risk of fragmen- 
tation of our field. Yet, at the same time, there remains an underlying concern, at times an outright worry, about being recognized by the university and by other disciplines.

These turns have also been impacted by fashions, with their inhibiting effect: see for instance the dominating reference to Vinay-Darbelnet in Québec or the interpretive theory in France, in the years 1980 - 1990; the dominating reference to the Skopos theory and the constant use of the Think Aloud Protocol in years 1990; the dominating reference to Venuti's agenda in the years 2000; the dominating reference to Bourdieu or the cognitive framework in the last years. The shift has been from a focus on text to a focus on the translator (black box and social agent), even though, at the same time, there is insistence of dealing with translation as a service, as an industry - thus, the current paradox to give up textualist approaches as if translators were in sole command.

Certain taboos can be added to the denials and fashions. To name a few:

- Regarding the underlying ideologie of the Skopos theory which fits the efficiency of communication in a mode of competitive production, of the concept of agent (and the risk management), of localisation resorting to workflow.

- Regarding the status of working languages, concealing languages less widely used and less taught and languages of migrants (e.g. Chinese, Korean in a bilingual Canada; the position of Arabic in the translations and interpretations in France).

- Regarding directionality (translating and interpreting into the mother tongue only?) and the relationship between bilingualism and interpreting: there are dogmas which have been banned for a long time in TS because the command of foreign languages is a necessary but not sufficient condition when translating or interpreting — dogmas formulated by scholars from dominant cultures.

- Regarding the economic dimension of the different modes of translating and interpreting: this dimension has long been repressed while today questions are asked about the cost of a poor quality of a translated document, of a service provided with no competences (see 3.3).

- Regarding self-translation by academics - that would explain the strong reluctance of the universities to have a language policy while acknowledging at the same time language diversity.

- Regarding the alleged necessary step to master consecutive interpreting before simultaneous interpreting.

- Regarding the translating body — the translating act being both incorporated (with rhythms, tensions and stress) and incorporating (the document to be translated is « assimilated », sometimes up to cannibalism).

The internationalisation of works and thoughts in TS makes us believe that there will be more and more inquiries about those turns, fashions, dichotomies and taboos.

\section{RAPID CHANGES IN TRANSLATION PRACTICES}

\subsection{Changes in the perception of a profession}

Today, we operate in a more technologized society, within a complex, competitive system of client and user expectations, tools, and new forms of organizations and work conditions. The new collaborative economy is changing dramatically production and 
consumption of goods and services. It also challenges the concept of profession, as if we were pushed back to be on piece-work, like in the $19^{\text {th }}$ century. Services such as Airbnb (an online marketplace where people can list, find, book and rent vacation homes), Uber (a multinational online transportation network company) offer occasional jobs and disturb steady and regulated professions. On the other hand, they also tend to be more and more professionalized, moving away from their original, starting idea. Moreover, the difference between producers and consumers is getting blurred: you can be "prosumers" of information, data, news, reports, services regarding cars, parking, flats, food, equipment, etc.

It is not the place to deal with the paradoxes, drawbacks and contradictions of the collaborative economy ${ }^{3}$. What we would like to underscore here and now is the impact of the changes in the perception of a profession. The Internet, artificial intelligence, robotics, production in $3 \mathrm{D}$, and the development of fab labs and maker spaces change employment, disrupt professions. What would be tomorrow the use of civil servants, translators, travel agents, insurance brokers, salesmen, lawyers, chemists, journalists, drivers, maybe even teachers if they can be replaced by different automation systems? Not only manual workers, technicians but also white-collar workers are under threat.

\subsection{Impact of technology on the practices}

Computer-aided translation (CAT) tools and Machine Translation (MT) (TAUS, 2013: $15-24,37-40$ ) have revolutionized, and continue to revolutionize, the practice of translation and they are altering both the perception of translation amongst users and the conceptualization of translation amongst producers and theorists. For the general user, automatic translation programmes, whether online or on a smartphone, give the impression (indeed even provide a reality) that translation is an instantaneous activity. The quality they achieve can be quite high, depending on genre conventions and language proximity, and then the question becomes "do I pay for a slightly better human translation when I can get a reasonable one for free?" The role of the translator has shifted and one can anticipate a time not too far off when the intervention of the human translator will be almost entirely centred on post-editing/quality assuring MT output or on providing very high quality translations of quality-sensitive texts such as publicity material, literary texts and legal documentation.

In less than two decades we have seen computing move through the ranks of the translation world - transforming the translator's resources and making it possible to accelerate the pace of translation. From the denial of translation we seem to have gone to a desire to translate, at times quite frenetically, as can be seen, for instance, with the fansubs and fandubs who appropriate a film in order to subtitle or dub it in the shortest possible delay.

The computerized components of the work environment have proliferated. The software used for creating translation memories, aligning texts, managing terminology, checking spelling and grammar, accessing and searching electronic corpuses, and

${ }^{3}$ Collaborative economy has been the butt of criticism regarding among other things the labor law, the tax law, competition rules. 
machine translation readily come to mind - without forgetting that many differently combined technologies also exist, such as those integrating translation memories, terminology bases and machine translation, all of which allows bidding for free translation to transpire and circulate on the Web. No less negligible is the sharing of experiences thanks to discussion lists and forums, blogs and various social media like LinkedIn.

From the use of micro-computers exponentially facilitating data-sharing and the creation of local networks, we have now moved to a kind of dematerialized computing (cloud computing) which lifts from the translator's shoulders all the worries and burdens of management, maintenance and reconfiguration of work tools; indeed, infrastructures, platforms, software, services and solutions are now accessible by distance, via Internet, and invoiced according to use (SaaS, or Software as a Service). This new online distribution model of shared tools pushes the translator to become member of an international virtual and collaborative community, since the updates and new versions are immediately available and everybody benefits. Such services in translation address professional, amateur and occasional translators, as well as agencies, institutions, and companies. They are able to propose such functionalities as project management, revision, terminology or a complete work environment. Among them, free or paid for, are: Translation Workspace, Wordbee, XTM Cloud, Google Translator Toolkit, Lingotek.

This rapid evolution is not inconsequential for the practice of translation, nor on the organization of its practice and surely not on its supply. Shared resources accessible in real time are now dynamic; costs are reduced (nothing is bought, as price setting is based and calculated on-demand or according to use, i.e. by the hour, year, volume of words, etc.); management is shortened (both in terms of time and transparency); work is shared. Dematerialization favours simplification and productivity. On the other hand, it also creates a certain dependence on Internet connections and poses problems concerning security and confidentiality breaches.

Based on the preceding information, one cannot conclude that the ongoing changes boil down solely to developments in machine translation, offered freely for all on the Web. Here we will differentiate between:

1. Machine translation offered through programs available on the Web, and where human intervention is limited.

2. Amateur translation ${ }^{4}$ that is also automatized but where the user provides his or her feedback, and at times attempts to improve the performance of the MT results without there being any specific translation training involved, based on linguistic intuition. Within this category, two types can be differentiated:

a. Translation by fans (fan translation, fan subbing, fan dubbing, scan-trans) who deliberately choose a manga, an animated film, a video game... and proceed to translate (subtitle, dub) it in order for others to know about it as soon as possible. These fans are not translation professionals - hence, they

${ }^{4}$ The terminology used in English is redundant and vague: community / crowdsourcing / collaborative / citizen / paraprofessional / user-generated / volunteer translations, in addition to the 3CT proposed by Common Sense Advisory, to wit: community, crowdsourced and collaborative translation. 
transgress certain conventions and respected norms of the profession (for example, for subtitling, this touches on the number of lines, scrolling speed, position, typographical characters used, gloss additions, etc.). Neither are they all 'pirates', as some of them do respect the copyright holders and refrain from circulating their translated version on the Web as soon as the book or film has officially been released.

b. Participatory or collaborative translation (crowdsourcing), used - for example - in the localization of software, Web sites or for translating articles, reports, literary texts and interviews. For this collective, unpaid effort, volunteer and anonymous (or sometimes not) participants turn to linguistic competence and during their available time here and there translate a sentence, a paragraph, a page... all of which can be retranslated and revised by others, until the entire project is finished. These volunteers translate once, or can translate hundreds of times, thanks to such tools as Traduwiki, Wikitranslate and Google Translate. Social media or socio-digital networks (Facebook, Twitter, LinkedIn, etc.) take advantage of the passing craze in order to become more accessible to more people.

Collaborative translation has already been subject to fiercely articulated positions, under the pretext of the pitiful quality it offers, or of the disloyal competition against professionals it causes, because it can be used just as easily by the non-profit sector as by the for-profit one.

The volume of potentially available translation work goes beyond the capacity of all professionals put together. Translation does not have equal prestige or the same attraction that music, photography, journalism or cinema has on the Web, with millions of amateurs ready to promote, without any compensation whatsoever, the products they are passionate about, as a pastime. Denied for so long, translation does not generate the same enthusiasm. Nonetheless, we can discern that the means (and tools) we have today are making translation desirable, and feasible. But, this desire is not an overwhelming one. These resources do not incite the masses even if they do allow us to envision breaking certain linguistic barriers, in view of the potential quantity of documents to be translated. The impact of crowdsourcing on the translation industry will be limited, despite the current euphoria of the discourse, and it will be most evident in only very visible instances.

3. Teamwork that is carried out on a same, single document by professionals places dematerialized computer resources at the common disposal of all. This includes document research, terminology, re-reading and revision. It is manifest in such sites as Proz, Translator's Café, etc. "Cloud" cannot be confused with "crowd".

4. Translation with open source tools, which are not necessarily free but which can be adapted to certain needs and redistributed to others, can be carried out by professionals, on a full-time basis.

5. Volunteer networked translation can also be carried out by professionals (that is to say, those who have been trained for translation and/or have experience in translation), for example through networks such as Babel, ECOS, Translators without Borders, 
etc. (Gambier, 2007a). These activist translators work for a specific cause, and respond to the needs expressed by NGOs (Non-governmental organisations) and other associations. Their network is aligned with a specific social cause / activity, or allied with actions expressing certain values.

Thus, there is a difference between types $1-2$ and $3-5$, where (for the latter) professionals share tools, problems and solutions and put an end to individualism or to a romanticized image of the translator, and where their socio-professional enterprise is reconfigured due to technologies being implemented to meet the challenges of outsourcing, competition, job insecurity, online bidding, international RFPs (Requests for proposal), etc. For types $1-2$, however, their only link is technological in most cases, with their common interest focusing on a site, a network, a product, etc. These "communities" on line are therefore short-term and limited in breadth and scope. What brings all these groups together is a shift in the direction towards the actor (translator, user), as the producer of content. Collective intelligence put into the service of translation has diverse motivations. Some Internet users are professionals, and concerned with developing their job profiles, others are activists clearly oriented by ideology, others are technophile amateurs, and still others are freelancers attempting to forge new niches... The evolution is thus not only technical, but also economic and social. It is constrained by outsourcing, but equally pushed forward by multilingual production needing to be rendered accessible as quickly as possible, or by the rallying behind certain causes that have been ignited...

\subsection{A multi-faceted market}

The market evolves according to demand, to the means used to meet these demands, and to the nature of the relationship that binds the translator to the commissioner of translations (Gouadec, 2002: 87-115; 2007: 120-145).

This market may be local, open and accessible to everybody, i.e. to anybody, from the person knowledgeable about the language needed, to the person able to manage a given tool or technology. This market is also fragmented, offering small irregularly paced contracts, and encompassing a variety of texts of unequal tenor and length from hotel pamphlets to promotional prospectuses of SMEs. It is equally the domain of freelancers - of amateurs (with hardly any training), beginners (new graduates, whether in translation or not), and professionals alike, where the latter are solidly established, have one or more working languages, and have been successful in gaining the loyalty of a certain number of regular clients.

A protected market implies a demand that is more concrete, one that touches on issues of quality requirements and on the translation of documents representing financial and commercial stakes, at times bound by security or legal constraints. Clients tend to be more well-informed, wanting their operations and maintenance manuals, marketing brochures, takeover bids, or Web sites to respect certain preferences of terminology and protocol of format. Likewise within this market we find translation agencies and companies, operating either with salaried in-house translators or functioning as a network of experienced, independent translators. The protected market can be regional, or national, and is configured mainly by medium-sized industrial and business enterprises, 
drawn in by the export field. In Finland, this type of market demands bi-directional translations, to and from foreign languages.

The global market is more or less concentrated. The management of projects, human resources and technical resources adheres to explicit standards and procedures of quality control, even if the work is outsourced and sub-contracted. Service providers (multinational agencies) are therefore organized along the lines of well-established criteria for reliability and productivity, with a division of labor that is more or less technically and geographically defined. They can respond to requests for huge volumes of translation and to a variety of demands, including diverse document types, languages to be used, and a specific infrastructure to produce the final product. This industrialized market of translation (including localization, multilingual writing and publishing) imposes specific norms, including financial ones, on multiple markets.

Regional and global markets can accommodate beginners on internships or for limited contracts, even if it means that after a certain period of time, these beginners might prefer sub-contracts from one or several contractors. Indeed, according to the market size and working languages, this market division can become more complex: in Finland it is rather rare to be able to survive as a literary, legal or technical translator; even agencies hesitate to hyper-specialize in any single domain - medical or pharmaceutical, for example. On the other hand, the arrival of multinational agencies, for instance in the audio-visual sector, has shaken up certain practices and fees. In fact, until translation work can be regulated, recognized, and accredited both in terms of access and practice, like other liberal professions (doctors, architects, lawyers, notaries, etc.), these three markets (local and open, regional and protected, global and concentrated) will continue to not be impervious to one another.

A non-negligible economic aspect on the market is the effect of competence in foreign languages on business performance, or in other words, how does a linguistic policy, often implicit, have an impact on the often non-explicitly stated policies of translation?

An international survey (2008) conducted by the British National Centre for Languages requested by the European Commission Directorate-General for Education and Culture, reveals that $11 \%$ of exporting European SMEs (945,000 firms) lose business due to linguistic barriers, ignoring that Russian, German and Polish are used in eastern Europe, or that French is current in a number of African countries, or that Spanish is spoken in Latin America! Less than half of these businesses have contemplated a strategy for multilingual communication (recruiting native speakers, adapting their Web site, resorting to local agents, offering language courses to personnel, hiring translators and interpreters).

The tangible missing economic link has been discussed on other occasions by Pym (Pym et al., 2006: 12), that is to say: the real questions of costs, investments, modes of payment, etc. From the multinational agency often managed today by a non-translator, to the publishing house anxious to conquer new markets (Heilbron et Sapiro, 2002; Sapiro 2008, 2009), and from the international or government institution remunerating translation services to the former teacher moonlighting in translation in order to make 
ends meet at the end of the month, economic and financial dimensions can no longer be neglected. They are relevant factors that orient, even determine, specific choices and decisions. Analyses would be welcome, such as, for example, on the linguistic policy and market of video games. However, micro-level studies need to accompany the macrolevel ones (see Mossop, 2006), for whichever domain the translations are done (medical, technical, commercial, audio-visual, literary, etc.), and they should:

- Compare translation and interpreting costs with the other means used for taking care of international multilingual communication (see section 1)

- Compare the ecological prints of Western translators with those in India translating the same text, or interpreters who travel versus those conducting videoconference interpreting (costs, productivity, and environment)

- Analyse translation as a bona fide business, notably in terms of its cost in relation to turnaround times and quality demands

- Analyse expenses in terms of the functioning, or non-functioning, of a translation division located within a business, banking or other enterprise

- Analyse the financial repercussions from translation memory systems in terms of productivity gains, or on the contrary, how they hinder due to ad hoc correspondences that emerge between segments and require change and correction, or what occurs when they are shared collectively or when substantial revision must be carried out on the translated text after they have been applied

- Analyse the costs and financial implications of software use in computer-assisted translation, machine translation with or without pre- and post-editing

- Compare modes of payment among translators (per word, line, page, hour, by the number of readers (of the translated text) or Web site visitors

- Document and analyse the economic fall-out when changes are made to the workflow, including new tasks, new procedures, new decision-making processes, changing relationships to the source document (completed or in the process of being written)

- Analyse the financial consequences of localizing, successfully or not, Web sites

- Analyse the costs for revision, re-reading, in accordance with their place and frequency along the workflow and in terms of expected objectives (for example, revising internally when the translations are outsourced)

- Analyse the financial impact of reverting solely to English for the international communications of a business organization (for example, the effects of a marketing piece or a slogan on actual sales)

- Document and analyse the means of selecting and recruiting independent / freelance translators by translation agencies, or by companies ... and the means by which to evaluate the services they have rendered

- Analyse the costs and effects of community interpreting, whether carried out by a qualified person or an amateur, in medical consultations (see survey 2008 by Ribera et al.)

- Analyse the relations between financial constraints, and the costs incurred for retranslations and/or for adaptations, with cuts and additions, for theatrical pieces, comics, children's literature, advertising, etc. 
From markets revolving around supply and demand to the effects of technologization, from daily organizational practices at work to the consequences of corporate mergers (corporate cultures), the territory and range are wide open for including research on the economic and financial dimensions of translation and interpreting. Many of those responsible for configuring the work terrain understand only the language of money.

\section{CURRENT TRANSFORMATIONS IN THE LANDSCAPE OF TRANSLATION}

\subsection{Different practices yesterday and today}

With all the changes implied by ICT, including the multimodal text, we can notice a multiplication of labels created nowadays for "translation". This outbreak in denominations has not yet occurred in all societies and in all languages. We are not thinking here of traditional categories such as specialized or literary translation, conference or community interpreting. Rather, we are thinking of the labels imposed from within diverse professional milieus - by sponsors and commissioners of translations, all the while denying the word itself, and opting instead for: localization, adaptation, multilingual documentation, editing, trans-editing, multilingual technical writing, language mediation, versioning, revision, co-writing (legal texts for ex.), transcreation (Ray \& Kelly, 2010), etc. The burgeoning functions to be carried out at the same time (documentation, terminology, project management, website design, editing and proofing), the advanced specialization required (by domain, tool, types of document) "define the sets of knowledge and specific competences for jobs as engineers of multimedia, multilingual communication" (Gouadec, 2002: 70).

The multiplication of labels to talk about translation is intriguing: it might also destabilize TS: what is then its object of investigation? However the destabilisation of TS has gone hand in hand with the expansion of the discipline in the past twenty years or so and has happily permitted a much broader perspective on the role of the translator. But let's come back to professions. How should we understand the situation and also the new hierarchy behind those labels? The term "translation" is rejected because it implies a formal transfer, a word-for-word work and because it goes with the traditional image of the translator as a subservient or "subaltern" worker (see 2.2 and 2.3). TS has deconstructed for some time now this definition and this image, and nowadays we deal with a concept of translation that recovers creativity, voice, interpretation, commitment. Nevertheless, today, different sectors use different labels, e.g. transcreation in the advertising industry ${ }^{5}$. In a way, the job market lags behind research but also associations are slow to update their categorization since most of them still rely on differences between literary and non-literary (technical, commercial, medical, legal) translators. To limit TS or our enquiries to institutionally visible or academically prestigious forms of translation is counter-productive: the inheritance of literary and religious texts is not obsolete but must be questioned to better include new practices.

5 A number of ads and TV news, for instance, are produced through a translation process but are not perceived as "translations" by their copywriters. 
Discrepancies in labelling are also confusing and difficult to overcome because if you work with certain term bases, translation memory software or certain Machine Translation (MT), you quickly realize that word-for-word is still there. But why should we expect experts in language industry to be different from managers in marketing regarding "translation"? (See 2.2). The popular assumption that translation is a linear substitution of words testifies to the somewhat archaic perceptions of "translation" and "translator" by many who have inherited and continue to propagate common archetypes, perceiving language as static rather than dynamic, envisaging communication as a mere sequence of information packets rather than as interactions.

How to redefine "translation" while not only practices are changing but the discussion in TS is becoming more and more international, opening up to other cultures (Tymoczko 2005, 2007)? To the concepts used in the past in Western Europe (mimesis, appropriation, imitation, commentary) must be added many concepts used in different cultural spaces of the contemporary world: Indian, Chinese, Arabic, Turkish, Malaysian, etc. (reversal, transmigration, metamorphosis, substitution, etc.) (Chesterman 2006; Gambier \& Stecconi 2019). Translation is a polymorphous concept to be negotiated, requiring to question the epistemological and social relevance of the studies in translation - in the way data, methods of investigation are selected, in the ways the scholar (practitioner and epistemic subject) takes a stand on the practices, the contingent realities. As long as translations were limited to conventional genres (contracts, patents, articles, instructions, pages of fiction), in well-defined domains (economic, scientific, military, agricultural, energy, etc.), for clear needs, analytic and interpretative grids were possible from your own experiences. How is it now when environments are changing with ICT, when documents are multimodal, when constraints in production and distribution of international multilingual communications are far from the known models (Pym 2004)?

\subsection{Paradigm shifts in Translation Studies}

Two paradigms are evolving, and justify to some degree the current multiplication of labels created for "translation". On one hand, the more conventional conceptualization of translation that has endured for centuries through the paradigm of equivalence, has evolved into one more oriented toward the public or audience targeted, i.e. the paradigm of the 'cultural turn'. It exists concurrently with another changing paradigm, one which reflects the platforms and mediums through which the activity of translation is now carried out. In this sense, the paradigm of the book (upon which the paradigm of equivalence is based) transforms into one of the digital and Web. Within the "cultural turn" in TS, several perspectives in particular have contributed to the critique of the long standing equivalence paradigm - Descriptive Translation Studies (Toury, 2012); the Skopos theory (Reiss \& Vermeer, 2013); and cultural politics (Venuti, 2008), among others. Translation is thus viewed as a process of re-contextualization, as a purposeful action. Translators consider and balance diverse factors during the translation process, in order to achieve a communicative purpose, and their translations materialize as functionally adequate in the target culture. The entire decision-making process is bound to considerations that involve the client end-receiver. Meaning is no longer considered as a mere invariant in the source text, but rather as culturally embedded, with a need 
to be interpreted. Translation becomes not just a lexical hurdle to overcome, but the result of connections between text, context, and myriad agents.

However, the long story of "translation" in our countries cannot be changed in a flash. It still heavily influences the current and popular ideology of "translation". The double clash of paradigms - from the "equivalence" paradigm to the paradigm of the "cultural turn" and from a tradition based on religious texts and printed matters to digital culture - is happening now. Hence the hesitation in denominating what we do when we translate or transcreate, transedit, localise.

\section{TOWARDS AN ORGANISATIONAL STRENGTHENING?}

A discipline can be defined by its epistemological elements (in particular its object of investigation) and its socio-institutional elements. We have emphasized the increase in the number of labels of the practices and the number of concepts (see section 4). In addition, translation, adaptation, localisation, intercultural studies are variously developed, in terms of geographic and institutional coverage but don't they all wonder about our ways of managing the communicational differences, at the semiotic, linguistic and/or cultural level, although they cope with moving concepts such as culture, context, norms?

Could TS become a trans-discipline, a transversal object of inquiry, common to psychologists, linguists, historians, philosophers, sociologists, economists, etc., shaking up at last the established disciplines? Nonetheless, must we have separated Translation Studies, Adaptations Studies, Intercultural Studies, Transfer Studies, Knowledge Management, Internet Studies, Web Science, Mediology, to name a few new fields? This does not imply that TS has to be cannibal of neighbouring disciplines. One has to acknowledge the complexity of communications and behaviours.

Another aspect is the institutionalisation of translation (with training programmes, associations, codes of ethics) and of TS (with research projects, doctoral schools, conferences and other international meetings, journals, specialised series, etc.) (Gambier 2007b) This institutionalisation has been partly criticized recently for being too much Eurocentric (van Doorslaer \& Flynn 2011). Neither translation nor TS have clear-cut borders. However, for institutional and logistic reasons, they are often strongly marked geographically, assimilated to a given space - i.e. for a journal such as TIS of the American Association of Interpreting and Translation Studies, for an association such as CATS/ACT in Canada, for an article such as "Italian TS".

There is a dual move today: the national, regional associations coexist with specialised ones. On the one hand, we have associations which continue to believe that the job is singular, the corporation is homogenous and depends on the passport; on the other hand, we have associations based on domains (legal, audio-visual, medicine, commerce, etc.) or based on the status (freelances, authorised translators, employees), and we should not forget websites such as Proz, Translators Café, Aquarius. In this fragmented landscape (there are more than 100 associations in the 28 EU countries), no one asks the question why to translate and not to learn more languages, to use passive bilingualism (see section 1).

All these associations are facing new problematics and new challenges, very different from what was happening in the late 1980. Networking is now preferred 
to the gatherings with formal rules and local branches. Today a certain number of TS associations exist: CATS/ACT, Canada, since 1987, EST since 1992, ABRAPT (Brazsil, 1992), Japan Association of Interpretation Studies (JAI, 2000), the Nida Institute within the American Bible Society (2002), AIETI (since 2003) for the Iberian Peninsula, ATISA (USA, 2003), IATIS (2004), SEPTET (Société d'études des pratiques et théories en traduction, 2005) and then come specialised associations, such as EAMT / for machine translation, AIIC / for conference interpreters. All these associations search for more visibility, as the transnational associations of translation companies, such as EUATC (European Union of Associations of Translation Companies). Rather than waiting for an utopian international organisation, they could gather in a unique network in order to lobby public and financial authorities, to struggle against any kind of censorship and violation of human rights (especially the freedom of expression) and to promote research $\mathrm{TS}$ in the international rankings of publications, etc.

\section{CONCLUSION}

The different issues raised in the five sections shake up TS as the discipline has been developing until recently. It is a sign of vitality. By analogy, would we accept to trust a doctor who would have a knowledge of medicine dated from research on rabies, tuberculosis and ignorant of cancers, HIV, Ebola virus? TS cannot any longer be satisfied with research based on canonical literature and conventional religious texts. The concept of text has nowadays expanded since it covers multimodal texts (texts with other semiotic signs than just verbal signs). And with this expansion, the concept of authorship has also been changing: while a literary text is usually transmitted thanks to a single author (at least in the Western written tradition), the moving text (Pym 2004) is produced, distributed, thanks to a set of stakeholders (combining authors, engineers, marketing staff, designers, localisers, etc.). For sure, there are still known unknowns in TS (Brems et al. 2012). The community of TS scholars is not so large that the discipline could have now a break (see Gile 2012): not only the object of inquiry is becoming more complex but the imaginary of translation, depicted in the use of metaphors and new narratives (in theoretical texts, in paratexts and in ordinary talks) is also slowly changing.

(C) Yves Gambier, 2019

\section{REFERENCES}

Brems, E., Meylaerts, R. \& van Doorslaer, L. (eds.) (2012). The Knowns unknowns of Translation Studies. Target, 24 (1).

Buzelin, H. (2014). How devoted can translators be? Revisiting the subservience hypothesis. Target, $26(1), 63-97$.

Chesterman, A. (2006). Interpreting the meaning of translation. In M. Suominen et al (eds.). A man of measure: Festschrift in homage of Fred Karlsson on his $60^{\text {th }}$ birthday. University of Helsinki.

Delisle, J. \& Woodsworth, J. (eds.) (2012). Translators through history (Revised edition) 1st ed. 1995. Amsterdam: John Benjamins.

Doorslaer, L. van \& Flynn, P. (eds.) (2011). Eurocentrism in Translation Studies. Translation and Interpreting Studies (TIS), 6 (2). 
Gambier, Y. (2003). Working with relay: An old story and a new challenge. In L. Perez González (ed.). Speaking in tongues: Language across contexts and users, 47-66. PU València.

Gambier, Y. (2007a). Réseaux de traducteurs/interprètes bénévoles. Meta, 52 (4), 658 - 672.

Gambier, Y. (2007b). Y-a-t-il une place pour une socio-traductologie? In M. Wolf \& A. Fukari (eds.). Constructing a sociology of translation, 205-217. Amsterdam: John Benjamins.

Gambier, Y. (2012). Le traducteur défiguré? In E. Skibínska \& N. Paprocka (eds.). Figure(s) du traducteur. Wroklow: PU (coll.Romanica Wratislaviensia, vol. 59).

Gambier, Y. \& Stecconi, U. (eds.) (2019). A World Atlas of Translation. Amsterdam: John Benjamins.

Gile, D. (2010). Why TS matter. In Gile D., Gyde H. \& Pokorn, N. (eds.). Why Translation Studies matter, 251-261. Amsterdam: John Benjamins.

Gouadec, D. (2002). Profession: Traducteur. Paris: La Maison du traducteur. In English (2007) Translator as a profession. Amsterdam: John Benjamins.

Heilbron J. \& G. Sapiro (éds.) (2002). Traduire: les échanges littéraires internationaux. Actes de la Recherche en Sciences Sociales, 144.

House, J. (2003). English as a global lingua franca. In L. Perez Gonzáles (ed.). Speaking in tongues: Language across contexts and users, 19-46. PU València.

Kalinowski, I. (2002). La vocation au travail de traducteur. Actes de la Recherche en Sciences sociales, 144, 47-54.

Lambert, J. (1989). La traduction, les langues et la communication de masse. Les ambiguïtés du discours international. Target, 1 (2), 215-237.

Mossop, B. (2006). Has computerization changed translation? Meta, 51 (4), 787-792.

Pym, A. (2004). The Moving Text. Amsterdam: John Benjamins.

Pym, A. (2009). Natural and directional equivalence in theories of translation. In Gambier, Y. \& van Doorslaer, L. (eds.). The Metalanguage of Translation, 81-104. Amsterdam: John Benjamins.

Pym A., Shlesinger, M. \& Z. Jettmarová (eds.) (2006). Sociocultural aspects of translating and interpreting. Amsterdam: John Benjamins.

Ray, R \& N. Kelly (2010). Reaching new markets through Transcreation. When translation just isn't enough. Common Sense Advisory.

Reiss, K \& Vermeer, H. (2013). Towards a general theory of translational action: Skopos theory explained. Manchester: St Jerome.

Ribera JM, S. Hausmann-Muela, KP. Grietens \& E.Toomer (2008). Is the use of interpreters in medical consultations justified? A critical review of the literature. (www.passsinternational.org).

Sapiro, G. (dir.) (2008). Transaltio. Le marché de la traduction en France à l'heure de la mondialisation. Paris: Ed.du CNRS.

Sapiro, G. (dir.) (2009). Les contradictions de la globalization éditoriale. Paris: Nouveau Monde éditions.

Simeoni, D. (1998). The pivotal status of the translator's habitus. Target, 10 (1), 1-39.

TAUS, Translation Automation User Society. https://www.taus.net/ (2013). Translation Technology Landscape Report. Online, 74 p.

Toury, G. (1995/2012). Descriptive Translation Studies and Beyond. Amsterdam: John Benjamins. 
Tymoczko, M. (2005). Trajectories of research in TS, Meta 50 (4), 1082-1097.

Tymoczko, M. (2007). Enlarging Translation, Empowering Translators. Manchester: St Jerome.

Venuti, L. (2008). The Translator's Invisibility. A History of Translation. London: Routledge. $1^{\text {st }}$ ed. $1995,3^{\text {rd }}$ ed. 2018.

\section{Article history:}

Received: 10 January 2019

Revised: 18 March 2019

Accepted: 25 March 2019

\section{История статьи:}

Дата поступления в редакцию: 10 января 2019

Дата принятия к печати: 25 марта 2019

\section{Bionote:}

YVES GAMBIER is a professor emeritus from the University of Turku (Finland), School of Languages and Translation Studies. With more than 200 publications, his research has focused on socio-terminology and special discourse, Translation Studies, Discourse analysis, bilingualism in Finland, early bilingual education, audiovisual translation, training of translators and interpreter. He is a member of the editorial boards of multiple journals such as Babel, Hermeneus, MonTI, Target, Terminology, Sendebar, Hermeneus, Synergies, TTR and the general editor of Benjamins Translation Library.

Contact information: e-mail: yves.gambier@utu.fi

\section{Сведения об авторе:}

ИВ ГАМБЬЕ — почетный профессор Университета Турку (Финляндия). Автор более 200 публикаций, посвященных социо-терминологии и специальному дискурсу, переводоведению, дискурс-анализу, двуязычию в Финляндии, двуязычному образованию в раннем возрасте, аудиовизуальному переводу, подготовке устных и письменных переводчиков. Является членом редколлегий нескольких журналов, таких как Babel, Hermeneus, MonTI, Target, Terminology, Sendebar, Hermeneus, Synergies, TTR, а также главным редактором Benjamins Translation Library.

Контактная информация: e-mail: yves.gambier@utu.fi 